Eksergi, Vol 17, No. 2. 2020

ISSN: $1410-394 \mathrm{X}$

\title{
The Growth Mechanisms of Atomic Layer Deposition: An Overview
}

\author{
Edy Riyanto $^{\mathrm{a}^{*}}$, Erie Martides ${ }^{\mathrm{a}}$, Endro Junianto ${ }^{\mathrm{a}}$ and Budi Prawara ${ }^{\mathrm{b}}$ \\ ${ }^{a}$ Research Center for Electrical Power and Mechatronics, Indonesian Institute of Sciences, Bandung 40135, Indonesia \\ ${ }^{b}$ Research Center for Electronics and Telecommunication, Indonesian Institute of Sciences, Bandung 40135, Indonesia
}

\section{Artikel histori :}

Diterima 7 September 2020

Diterima dalam revisi 28 September 2020 Diterima 15 Oktober 2020

Online 31 Oktober 2020

\begin{abstract}
In this review, the discussion emphasized on the growth mechanisms of atomic layer deposition which consists of a theoretical model and experimentally growth as well as the measurement testing as evidences. The deposition process description with some testing evidences can be used to facilitate in the effort to understand the basic concept of ALD growth mechanisms. Some metal oxides like $\mathrm{Al}_{2} \mathrm{O}_{3}, \mathrm{HfO}_{2}$, and $\mathrm{TiO}_{2}$ with these employed precursors are typically used for the detailed illustration during the reaction steps. Although the surface chemistry of ALD process has been well understood, systematic description which combine a theoretical and experimentally growth mechanism is still missing. This paper aims to provide a better understanding of ALD growth mechanisms and surface chemistry which eventually able to contribute on the thin film growth processing.
\end{abstract}

Keywords: atomic layer deposition; growth mechanism; thin film

\section{Introduction}

Atomic layer deposition (ALD) has played a significant potential role in modern technologies such as sensing (Graniel et al., 2018; Chen et al., 2020; Adhikari et al., 2019), solar cells (Delft et al., 2012; Ponraj et al., 2013), solid oxide fuel cells (Jiang et al., 2008; Johnson et al., 2014), lithium ion batteries (Meng et al., 2012; Meng et al., 2017), and photocatalysis (Edy et al., 2016; Edy et al., 2016). Increasing number on ALD research attention will give impact on the broadening applications in the future. Historically, ALD was invented by two research groups independently in different time without communications each other: a Russian group led by Aleskovskii (1960s) which called "molecular layering" (Puurunen et al, 2004) and a Finnish group led by Suntola (1970s) with the name of "atomic layer epitaxy" (Suntola et al., 1985). After growing number of the films development, in fact many of them are not in epitaxial condition, and it may leads to replace the atomic layer-by-layer processing growth name to become an atomic layer deposition instead of atomic layer epitaxy.

For some film characteristics, the thin layer obtained by using ALD is considered to be an unreplaceable process. These merits are conformal deposition on the complicated contour surface, uniform thickness all over the deposited substrate even in the 3D porous surface, and precision control of the thickness. One of outstanding ALD process which typically able for growing materials at low temperature deposition has attracted application in the field of soft material substrates which sensitive to the thermal stability. As ALD process enabling for many various metal oxide materials, this technique is beneficially during the growth deposition of inorganic films on organic substrates. This growth technique leads to expand significantly the unprecedented applications which currently still under actively exploration.

Although ALD has currently gained more attention on the exploration for applications, a basic principle of ALD growth is still required to be expanded to get a better growth technique. In this review paper, the discussions are stressed on the growth mechanism of various ALD materials onto substrates, the influence of prominent parameters on the growth, and the science related with ALD growth to achieve a high quality layer with approaching of both a theoretical model and an experimentally evidence. For easy understanding, the growth illustration uses a certain ALD material as an example which typically metal oxide.

\section{Principle of ALD Growth and Initial Surface Reaction Mechanisms}

Atomic layer deposition is a sophisticated method for a thin film deposition of noble metals and metal oxides due to the ability to provide uniform and conformal films on planar substrates, a high aspect ratio structures, and $3 \mathrm{D}$ porous materials. For smoothly growing, polar groups (i.e. $-\mathrm{OH}$ ) with high density is expected to be exist on the surfaces.

Basically ALD can be expressed with four steps as illustrated in Fig. 1: (a) the precursor exposure (i.e. $\mathrm{Al}\left(\mathrm{CH}_{3}\right)_{3}$, Trimethylaluminum (TMA)) into ALD chamber to react with all reactive sites on the surfaces, (b) evacuation process of the reaction product (i.e. $\mathrm{CH}_{4}$, methane) and the excess precursor, (c) the reactant exposure (i.e. $\mathrm{H}_{2} \mathrm{O}, \mathrm{O}_{2}$, or $\mathrm{O}_{3}$ ) into the ALD chamber to react with the surface sites

${ }^{*}$ Corresponding Author: +62-22-2503055; fax : +62-22-2504773

Email: edy.riyanto@lipi.go.id 
generated by the first surface reaction, (d) purging process of the reaction product and the excess reactant. These four steps is called a cycle which able to grow a monolayer that has thickness of around $\sim 1 \AA$. These reactions can be described below (George, 2010; Xu et al., 2004; Kim et al., 2019; Kaipio et al., 2014; Jur et al., 2011).

(i) $\mathrm{Al}-\mathrm{OH}^{*}+\mathrm{Al}\left(\mathrm{CH}_{3}\right)_{3} \rightarrow \mathrm{Al}-\mathrm{O}-\mathrm{Al}-\left(\mathrm{CH}_{3}\right)_{2} *+\mathrm{CH}_{4}$

(ii) $\mathrm{Al}-\mathrm{CH}_{3} *+\mathrm{H}_{2} \mathrm{O} \rightarrow \mathrm{Al}-\mathrm{OH}^{*}+\mathrm{CH}_{4}$

(*) represents an active species.

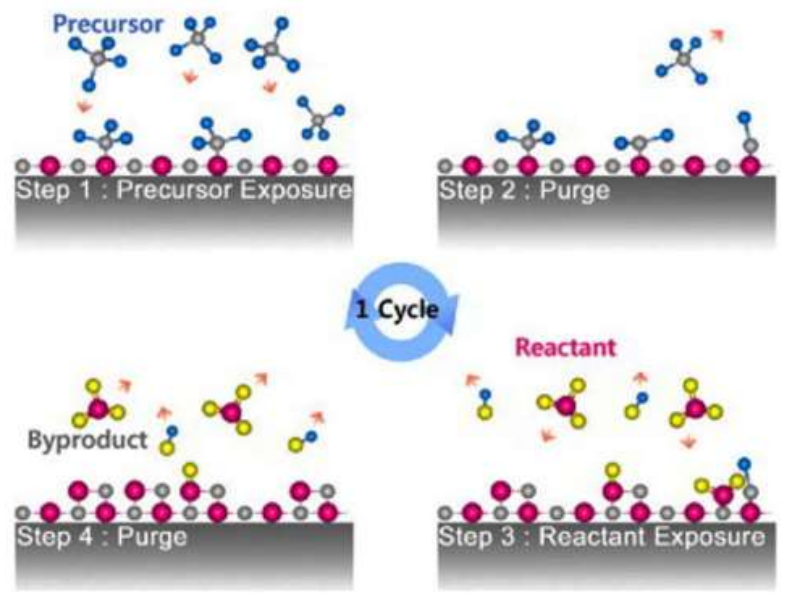

Figure 1. Schematic shows the ALD growth process. Reprinted with permission from ref.(Cheng et al., 2017)

In the initial growth step, it illustrates the first half interaction between functional -OH groups and precursor, in this case use $\mathrm{TiCl}_{4}$ and $\mathrm{H}_{2} \mathrm{O}$. In the first half-reaction, $\mathrm{TiCl}_{4}$ react with hydroxyl-OH groups which is initiated by the adsorption process. $\mathrm{TiCl}_{4}$ was adsorbed onto the all available $-\mathrm{OH}$ through a spontaneously coordination between $\mathrm{Ti}$ and $\mathrm{O}$ atoms and form a Ti-O bond with distance of $2.28 \AA(\mathrm{Hu}$ et al., 2006). For the second half-reaction, $\mathrm{H}_{2} \mathrm{O}$ molecules react with the surface intermediates of $\mathrm{TiCl}_{3} *$ surface sites to release $\mathrm{HCl}$ species as a product (Puruunen, 2003).

The detailed reaction mechanism of the first half ALD cycle is shown in Fig. 2. In the early coordination, Ti of $\mathrm{TiCl}_{4}$ collides the $\mathrm{O}$ atom at the $-\mathrm{OH}$ groups to form $\mathrm{HCl}$ (Fig.2(c)). During Ti and O interaction in the first half ALD exposure, negative charge at the donor $(\mathrm{O})$ is given to the acceptor (Ti) by forming Ti-O bond. Due to the accumulation of negative charge at the $\mathrm{Ti}$ atom, it leads to rehybridize the $\mathrm{Ti}$ group from 5- to become 4-coordination by releasing a $\mathrm{Cl}$ atom. On the other hand, this phenomenon can stabilize a buildup of negative charge on the $\mathrm{O}$ and reduces the $\mathrm{O}-\mathrm{H}$ coordination. If the negatively charged $\mathrm{Cl}$ meets the positively charged $\mathrm{H}$ of the $\mathrm{O}-\mathrm{H}$ in the transition state, it leads to break the $\mathrm{O}-\mathrm{H}$ bond which eventually was formed a reaction product of $\mathrm{HCl}$.

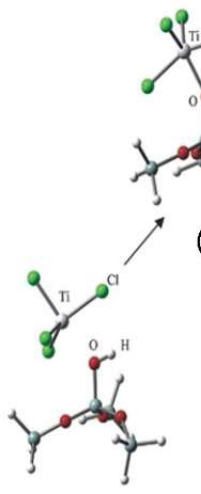

(a) (b)

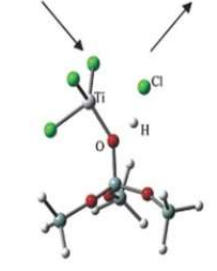

(c)

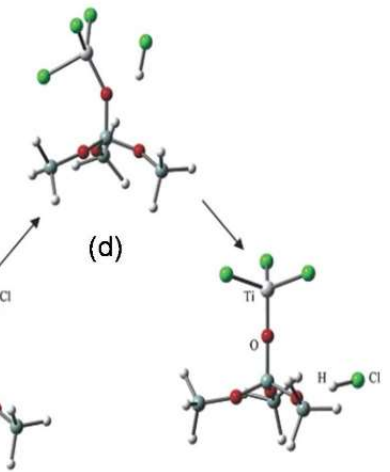

(e)
Figure 2. Illustration of the first half ALD reaction of $\mathrm{TiCl}_{4}$ and hydroxyl - $\mathrm{OH}$ : (a) first coordination between precursor and -OH site, (b) Ti-O bond was formed which has 5 coordination at the Ti atom, (c) transitional condition, (d) the product of $\mathrm{HCl}$ was formed, and (e) the first half ALD cycle was completed by removing the $\mathrm{HCl}$ product. Reprinted with permission from ref.(Hu et al., 2006).

\section{Non-growth Ligand Exchange Reaction}

In the growth mechanism at a certain ALD material, there is possibility that the ALD step on a half reaction will not get any deposition which called Non-growth ligand exchange reaction or NGLE. It is a surface reaction on ALD process without gaining metal deposition. As an illustration, the $\mathrm{HfO}_{2}$ ALD growth using Hafnium tetrachloride $\left(\mathrm{HfCl}_{4}\right)$ precursor is used for an example. For normal growth at the first half-cycle, the ligand exchange reaction which the $\mathrm{O}-\mathrm{H}$ bond dissociates and $\mathrm{H}$ atom of $\mathrm{O}-\mathrm{H}$ combines with a $\mathrm{Cl}$ atom of $\mathrm{HfCl}_{4}$ forms $\mathrm{HCl}$ as a product as shown in the reactions of (i) and (ii). The chemical reactions on the $\mathrm{HfO}_{2}$ formation consist of two half-reactions (Mukhopadhyay et al., 2006; Mukhopadhyay et al., 2008; Puurunen, 2004):

(i) $\mathrm{M}-\mathrm{OH}^{*}(\mathrm{~s})+\mathrm{HfCl}_{4}(\mathrm{~g}) \rightarrow \mathrm{M}-\mathrm{O}-\mathrm{HfCl}^{*}(\mathrm{~s})+\mathrm{HCl}(\mathrm{g})$

(ii) $\mathrm{Hf}-\mathrm{Cl} *(\mathrm{~s})+\mathrm{H}_{2} \mathrm{O}(\mathrm{g}) \rightarrow \mathrm{Hf}-\mathrm{OH}^{*}(\mathrm{~s})+\mathrm{HCl}(\mathrm{g})$

"M" represents a substrate.

Meanwhile, NGLE reactions in which $\mathrm{HfCl}_{4}$ precursor do not deposit metal and may lead to the incorporation of $\mathrm{Cl}$ in the film and lead to the formation of hydroxyl-chlorides of both Hydroxychloride $\left(\mathrm{HfCl}_{3} \mathrm{OH}\right)$ and hydroxychloride $\left(\mathrm{HfCl}_{2}(\mathrm{OH})_{2}\right)$ as well as oxychloride $\left(\mathrm{HfOCl}_{2}\right)$ as illustrated in the first-half cycle of (iii), (iv) and (v) (Mukhopadhyay et al., 2006; Heyman et al., 2004). These surface reaction mechanisms are considered to be detrimental due to it can cause surface roughness, reduce the electrical properties, etching effect, and reduction of the ALD process efficiency with reducing the growth rate.

(iii) $\mathrm{M}-\mathrm{OH}^{*}(\mathrm{~s})+\mathrm{HfCl}_{4}(\mathrm{~g}) \rightarrow \mathrm{M}-\mathrm{Cl} *(\mathrm{~s})+\mathrm{HfCl}_{3} \mathrm{OH}(\mathrm{g})$

(iv) $\mathrm{M}-\mathrm{OH}^{*}(\mathrm{~s})+\mathrm{HfCl}_{3} \mathrm{OH}(\mathrm{g}) \rightarrow \mathrm{M}-\mathrm{Cl}^{*}(\mathrm{~s})+\mathrm{HfCl}_{2}(\mathrm{OH})_{2}(\mathrm{~g})$

(v) $\mathrm{M}-\mathrm{OH}^{*}(\mathrm{~s})+\mathrm{HfCl}_{4}(\mathrm{~g}) \rightarrow \mathrm{M}-\mathrm{Cl}$ (s) $+\mathrm{HfOCl}_{2}(\mathrm{~s})+\mathrm{HCl}(\mathrm{g})$ 
These possible reactions of first half cycles are considered to be non-growth ligand exchange reactions. It can be seen that the NGLE reactions only involve the exchange of surface termination groups without gaining ALD material deposition.

\section{Interfacial Diffusion Growth}

Atomic layer deposition allows coating of thin film in a very precise way in Angstrom level. It was shown that ALD process will enable the inorganic materials to grow on the ubiquitous surface with or without hydroxyl groups. In the surface with numerous polar groups, the ALD material will be deposited normally onto the surface directly. Meanwhile the ALD growth on the surface without reactive sites, the initial growth is started by diffusion growth mechanism on the interfacial as illustrated in Fig.3.

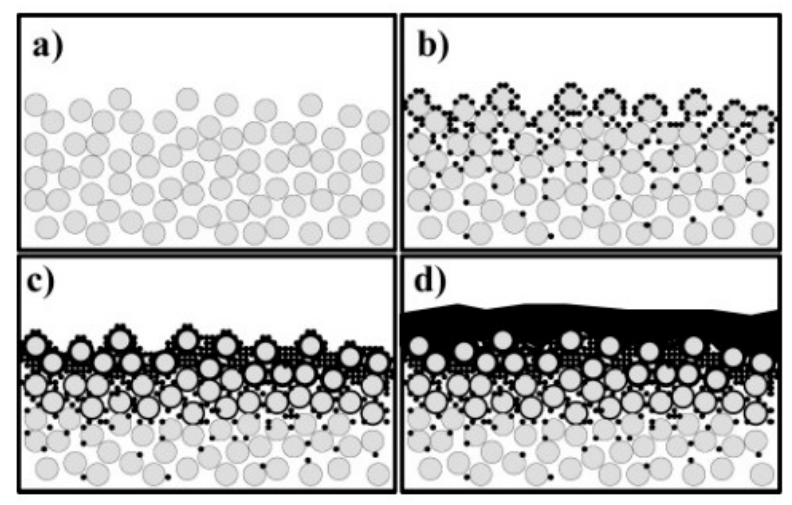

Figure 3. Schematic growth of $\mathrm{Al}_{2} \mathrm{O}_{3}$ deposited onto a polymer without polar groups (a) the porous structure of polymer without ALD coating, (b) aluminum oxide nucleation clusters due to the TMA and $\mathrm{H}_{2} \mathrm{O}$ molecules interaction, (c) coalesce of the clusters and covered all over porous structure in the surface region, and (d) the growth is started to the normally growth mechanism. Reprinted with permission from ref.(Wilson et al., 2005).

A polymer is a large molecule, or macromolecule composed of many subunits. A macromolecule is the structure of which essentially comprise the multiple repetition units. Polymer may consist of linear macromolecules containing each only one unbranched chain or branched macromolecule (i.e polyethylene). Structurally, polymers consist of numerous polymer chains with microporous structure that can be illustrated as cross section polymer in Fig.3(a). Initial growth mechanism on the polymer surface without hydroxyl groups is started with TMA molecules are infiltrated to the subsurface of the polymer film.

Subsequent exposure of $\mathrm{H}_{2} \mathrm{O}$ will react with TMA and produce $\mathrm{Al}_{2} \mathrm{O}_{3}$ nucleation clusters (Fig.3(b)). The subsequent cycle numbers will fill the space between polymer chains which eventually coalesce and close the space to be nearly continuous as shown in Fig.3(c). After the space between the polymer chains are totally closed, the TMA and $\mathrm{H}_{2} \mathrm{O}$ exposures lead to form $\mathrm{Al}_{2} \mathrm{O}_{3}$ ALD growth normally as illustrated in Fig.3(d). This continuous film will grow linearly in the interfacial region and block further precursors diffusion into the near surface. The required cycle number to get a continuous growth in the interfacial region may depend on the porous structure formed by polymer chains on the near surface region and the deposited ALD materials.
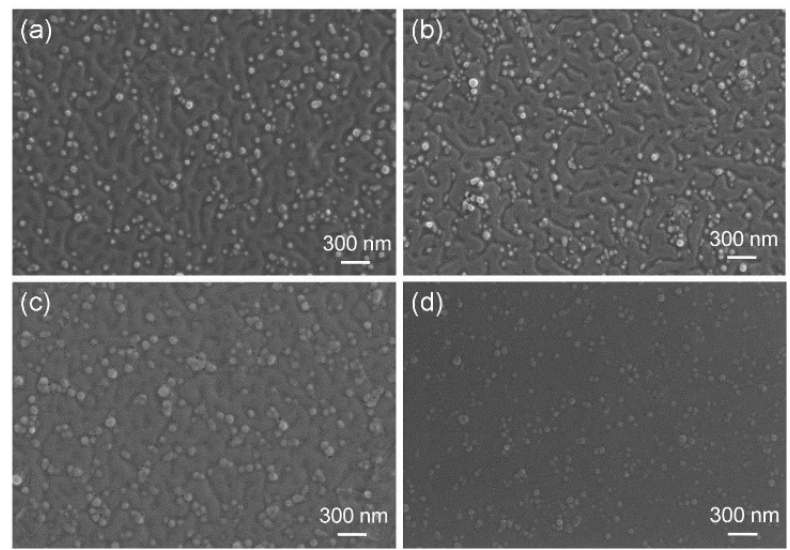

Figure 4. The front view images. (a) bare PET surface. PET surface covered by ALD layer of (b) $\mathrm{TiO}_{2}$, (c) $\mathrm{Al}_{2} \mathrm{O}_{3}$ with thickness of both are 100 cycles., (d) $\mathrm{Al}_{2} \mathrm{O}_{3} / \mathrm{TiO}_{2}$ bilayer with each of layer is 100 ALD cycles. Reprinted with permission from ref.(Edy et al., 2017).

It was shown the effect of ALD materials and the cycle number on the growth mechanisms onto polyethyleneterephthalate (PET) substrate as shown in Fig.4 (Edy et al., 2017). Figure 4 is PET surface image without ALD layer (Fig.4(a)) and the surface that has been coated by ALD of $\mathrm{TiO}_{2}, \mathrm{Al}_{2} \mathrm{O}_{3}$, and $\mathrm{Al}_{2} \mathrm{O}_{3} / \mathrm{TiO}_{2}$ bilayer (Fig. 4(b)-(d)). The smoothness of PET surface increases due to the presence of ALD films, and it further increases on the surfaces with better coverage as revealed in Fig.4(c)-(d). In term of $\mathrm{ALD}$ growth robustness, $\mathrm{Al}_{2} \mathrm{O}_{3}$ growth is better than that of $\mathrm{TiO}_{2}$ as indicated by the surface coverage of $\mathrm{Al}_{2} \mathrm{O}_{3}$ film is higher than that of $\mathrm{TiO}_{2}$ in the thickness of both are 100 ALD cycles. The film coverage which is indicated by surface smoothness, is furtherly increase by forming of $\mathrm{Al}_{2} \mathrm{O}_{3} / \mathrm{TiO}_{2}$ bilayer as shown in Fig.4(d). It is due the $\mathrm{Al}_{2} \mathrm{O}_{3}$ layer acted as base substrate for the $\mathrm{TiO}_{2}$ layer can be as a buffer layer. Structurally, PET has numerous functional groups of $\mathrm{C}=\mathrm{O}$ as carbonyl site (Edy et al., 2017; Edy et al., 2013). In the initial growth, the provided $\mathrm{C}=\mathrm{O}$ groups react to the elements of the precursors of the growth materials. In the early process, the deposition occurs on the near surface region. On the other hand, the coordination between precursor and polar groups can disrupt hydrogen bonding, which leads to the opening of chain framework which eventually able to promotes the nucleation diffusion into the 
near surface region (Spagnola et al., 2010; Knez, 2012). These phenomena of the ALD growth mechanisms can be clearly illustrated as shown in Fig. 4.

\section{ALD Growth Evaluation}

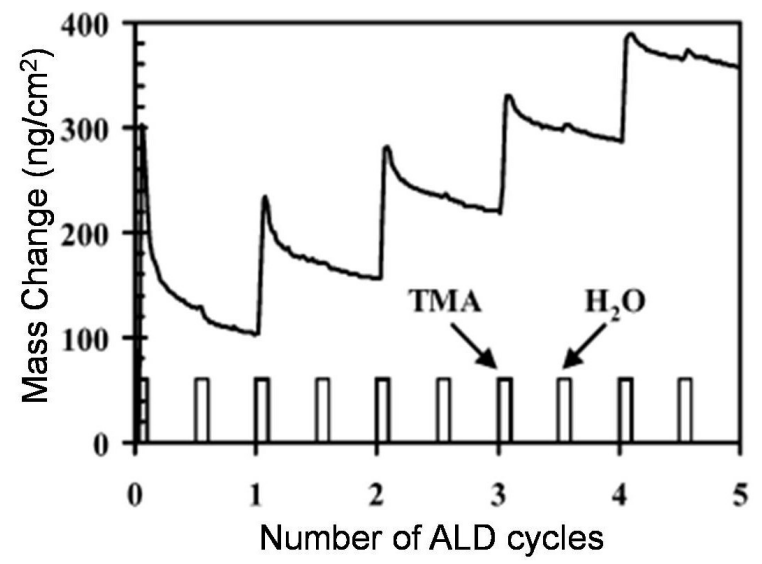

Figure 5. Mass gain on ALD deposition measured by using a Quartz Crystal Microbalance (QCM) as a function of ALD cycles on the $\mathrm{Al}_{2} \mathrm{O}_{3}$ deposition for 5 cycles. Reprinted with permission from ref.(Wilson et al., 2005).

Figure 5 shows mass change $\left(\mathrm{ng} / \mathrm{cm}^{2}\right)$ versus ALD cycles $(5$ cycles) during $\mathrm{Al}_{2} \mathrm{O}_{3}$ ALD deposition onto Polypropylene (Wilson et al., 2005). It was shown that the first TMA exposure led to increase a large mass up to $\sim 300 \mathrm{ng} / \mathrm{cm}^{2}$ which followed by a mass decrease to $\sim 125 \mathrm{ng} / \mathrm{cm}^{2}$ and it was continued by the $\mathrm{H}_{2} \mathrm{O}$ exposure as indicated with small peak which followed by a mass decrease as well. The mass gain increases linearly by increasing the cycle number forms a stair-like with a mass growth rate of $\sim 60 \mathrm{ng} / \mathrm{cm}^{2}$. These mass transients are consistent to adsorption and desorption processes during the surface reaction mechanisms. During adsorption processes of TMA or $\mathrm{H}_{2} \mathrm{O}$ molecules on the surfaces up to saturation stage as indicated by the mass increases up to the maximum point in the QCM signal and then followed by desorption of the ligand exchange reaction mechanism forms $\mathrm{CH}_{4}$ product which then evacuated through purging process. Furthermore, the mass decrease shown in the QCM measurement may also affected by the unreacted precursor molecules due to the excess precursor exposure which collide to the surfaces.

In the evaluation of growth mechanism, confirmation can be checked at each half cycle by using Fourier-transform infrared spectroscopy (FTIR) (Hyde et al., 2010). Figure 6 shows cycles process during $\mathrm{Al}_{2} \mathrm{O}_{3}$ deposition by using TMA $/ \mathrm{H}_{2} \mathrm{O}$ (Fig.6(a-b)) and $\mathrm{TMA} / \mathrm{O}_{3}$ as precursors and reactant (Fig.6(c-d)). Figure 6(a) is the spectrum after $\mathrm{H}_{2} \mathrm{O}$ exposure during an $\mathrm{Al}_{2} \mathrm{O}_{3}$ deposition. A positive peak at the range of $3640-3730 \mathrm{~cm}^{-1}$ corresponds to $\mathrm{O}-\mathrm{H}$ due to the presence of $\mathrm{AlOH}^{*}$ species. On the other hand, negative

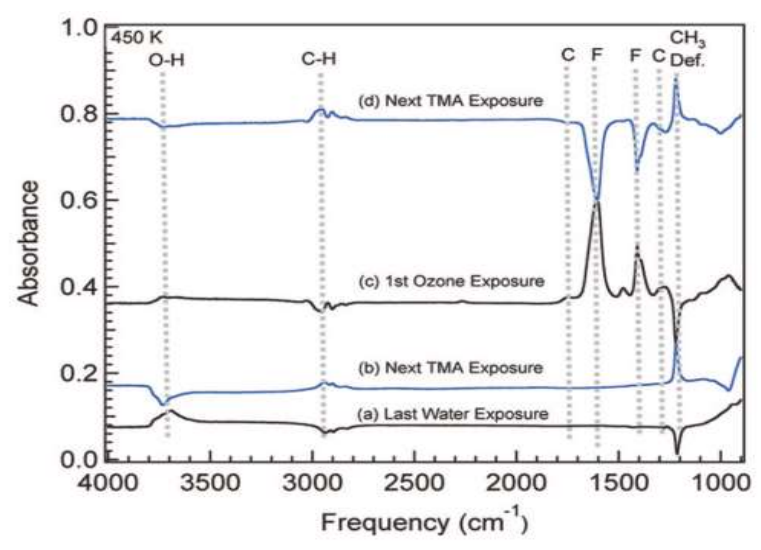

Figure 6. FTIR spectra phenomena in the condition of after (a) $\mathrm{H}_{2} \mathrm{O}$ exposure, (b) $\mathrm{Al}\left(\mathrm{CH}_{3}\right)_{3}$ exposure, (c) first $\mathrm{O}_{3}$ exposure, and (d) next $\mathrm{Al}\left(\mathrm{CH}_{3}\right)_{3}$ exposure. $\mathrm{C}$ = carbonate, $\mathrm{F}$ $=$ formate. Reprinted with permission from ref.(Goldstein, et al., 2008).

trend was shown at the range of $2920-2980 \mathrm{~cm}^{-1}$ corresponds to $\mathrm{C}-\mathrm{H}$ stretching and at $1212 \mathrm{~cm}^{-1}$ corresponds to $\mathrm{Al}-\mathrm{CH}_{3}$. These trends as a result of reaction between $\mathrm{AlCH}_{3}{ }^{*}$ species and $\mathrm{H}_{2} \mathrm{O}$ and release reaction product of $\mathrm{CH}_{4}$. Figure $6(\mathrm{~b})$ shows the FTIR spectra after TMA exposure. This exposure causes an alteration of $\mathrm{AlOH}^{*}$ become $\mathrm{AlCH}_{3} *$ surface species. The surface species change dramatically after the first $\mathrm{O}_{3}$ exposure as illustrated in Fig. 6(c). It was shown that the intensity of the $\mathrm{O}-\mathrm{H}$ stretching at the range of 3734 to $3778 \mathrm{~cm}^{-1}$ decreases compared to the intensity as shown in Fig. 6(a). Fig. 6(d) reveals that the features of Carbonate, Formate, and $\mathrm{O}-\mathrm{H}$ stretching vibration are totally disappeared by exposing of TMA. Conversely, the $\mathrm{C}-\mathrm{H}$ stretching vibrations emerges after the TMA exposures.

\section{ALD for Complex Structure Substrate}

ALD has been an unreplaceable growth method on various substrates ranging from planar surfaces to three-dimensional structure of nanoporous materials. Fig.7(a) shows an image of silicon trench substrate coated $\mathrm{Ge}_{2} \mathrm{Sb}_{2} \mathrm{Te}_{5}$ ALD film (Pore et al., 2009). The image demonstrates a smooth surface with perfectly conformal to cover all the exposed surface including the bottom of the trench with uniform thickness. Furthermore, Fig.7(b) shows three-dimensionally porous sponge originating from polyurethane deposited $\mathrm{TiO}_{2}$ film with 1000 cycles by ALD (Edy et al., 2016). These evidences indicate that ALD can be as a robust method for deposition onto the surfaces with complicated feature even on $3 \mathrm{D}$ porous structure. The superior characteristic of ALD process in term of conformality and uniformity deposited by ALD can be regarded to be unreplaceable process compared to any other deposition techniques. Atomic layer deposition is also benefited by the ability to be processed at low temperature of lower than $100{ }^{\circ} \mathrm{C}$ which is beneficially for deposition with low melting temperature substrate such as polymers. 


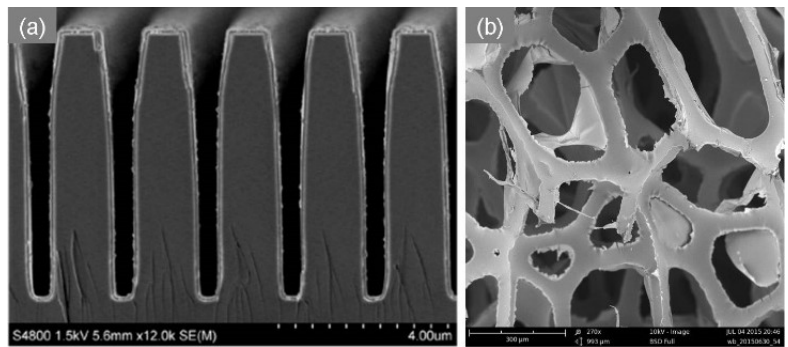

Figure 7. ALD thin film deposited on complex surfaces. (a) Cross-section image of trench deposited by $\mathrm{Ge}_{2} \mathrm{Sb}_{2} \mathrm{Te}_{5}$ ALD (Pore et al., 2009). (b) 3D porous sponge coated $\mathrm{TiO}_{2}$ by ALD (1000 ALD cycles) (Edy et al., 2016).

\section{Conclusions}

Atomic layer deposition can be successfully grown on both types of surfaces with and without functional groups. The growth mechanism on the substrate with numerous reactive surfaces groups like $-\mathrm{OH}$ and $\mathrm{C}=\mathrm{O}$ is initiated by a directly reaction between precursors and these reactive sites. In addition, the growth mechanism on the surface without hydroxyl groups is initiated by trapping the precursor molecules in the subsurface and forms nucleation clusters. By increasing the cycle number, the clusters will fill the region among the porous frameworks which eventually connected each other and close the space to be continuously covered by ALD material clusters. In the case of substrate that has numerous reactive sites with microporous feature in the subsurface region, the initial growth can be initiated by a normal reaction between reactive sites and reactant and on the other hand the diffusion growth mechanism concurrently in the near surface region. In the ALD growth process, the robust growth mechanism can be indicated with the adsorption and desorption processes during the surface reaction mechanisms. Furthermore, it can be indicated by the surface species change after the first- and second- half cycle during the ALD process. With these growth mechanisms, ALD process will enable the thin film materials to grow onto the complex surface uniformly even on the threedimensionally porous substrates.

\section{Authorship Information}

Edy Riyanto is the main contributor. The authors declare that they have no competing interests.

\section{Acknowledgments}

This work was supported by Center of Excellence on Science \& Technology for Renewable Energy (PUI EBT Puslit Telimek LIPI 2020) of Ministry of Research, Technology of Indonesia (Grant No. 381/M/KPT/2018).

\section{References}

Adhikari, S., Selvaraj, S. \& Kim, D.H., 2019, Construction of heterojunction photoelectrode via ALD of $\mathrm{Fe}_{2} \mathrm{O}_{3}$ on $\mathrm{Bi}_{2} \mathrm{WO}_{6}$ for highly efficient photoelectrochemical sensing and degradation of tetracycline, Applied Catalysis B: Environmental, Vol. 244: 11-24.

Chen, Y., Yuchi, Q., Li, T., Yang, G., Miao, J., Huang, C., Liu, J., Li, A., Qin, Y. \& Zhang, L., 2020, Precise engineering of ultra-thin $\mathrm{Fe}_{2} \mathrm{O}_{3}$ decorated Pt-based nanozymes via ALD to switch off undesired activity for enhanced sensing performance, Sensors \& Actuators: $B$. Chemical, Vol. 305: 127436(8p).

Cheng, N. \& Sun, X., 2017, Single atom catalyst by atomic layer deposition technique, Chinese Journal of Catalysis, Vol. 38: 1508-1514.

Delft, J.Av, Garcia-Alonso, D. \& Kessels, W.M.M., 2012, Atomic layer deposition for photovoltaics: applications and prospects for solar cell manufacturing, Semiconductor Science and Technology, Vol. 27: 074002(1-13).

Edy, R., Huang, G.S., Zhao, Y.T., Zhang, J., Mei, Y.F. \& Shi, J.J., 2016, Atomic layer deposition of $\mathrm{TiO}_{2}-$ nanomembrane-based photocatalysts with enhanced performance, AIP Advances, Vol. 6: 115113(1-9).

Edy, R., Zhao, Y.T., Huang, G.S., Shi, J.J., Zhang, J., Solovev, A.A. \& Mei, Y., 2016, $\mathrm{TiO}_{2}$ nanosheets synthesized by atomic layer deposition for photocatalysis, Progress in Natural Science: Materials International, Vol. 26: 493-497.

Edy, R., Huang, G.S., Zhao, Y.T., Guo, Y., Zhang, J., Mei, Y.F. \& Shi, J.J., 2017, Influence of reactive surface groups on the deposition of oxides thin film by atomic layer deposition, Surface \& Coatings Technology, Vol. 329: 149-154.

Edy, R., Huang, X.J., Guo, Y., Zhang, J. \& Shi, J.J., 2013, Influence of argon plasma on the deposition of $\mathrm{Al}_{2} \mathrm{O}_{3}$ film onto the PET surfaces by atomic layer deposition, Nanoscale Research Letter, Vol. 8(79): 1-9.

George, S.M., 2010, Atomic layer deposition: An overview, Chemical Review, Vol. 110: 111-131.

Goldstein, D.N., McCormick, J.A. \& George, S.M., 2008, $\mathrm{Al}_{2} \mathrm{O}_{3}$ atomic layer deposition with trimethylaluminum and ozone studied by in situ transmission FTIR spectroscopy and quadrupole mass spectrometry, Journal of Physical Chemistry C, Vol. 112: 1953019539.

Graniel, O., Weber, M., Balme, S., Miele, P. \& Bechelany, M., 2018, Atomic layer deposition for biosensing applications, Biosensors and Bioelectronics, Vol. 122: 147-159.

Heyman, A. \& Musgrave, C.B., 2004, A quantum chemical study of the atomic layer deposition of $\mathrm{Al}_{2} \mathrm{O}_{3}$ using $\mathrm{AlCl}_{3}$ and $\mathrm{H}_{2} \mathrm{O}$ as precursors, Journal of Physical Chemistry $B$, Vol. 108: 5718-5725.

Hyde, G.K., Scarel, G., Spagnola, J.C., Peng, Q., Lee, K., Gong, B., Roberts, K.G., Roth, K.M., Hanson, C.A., 
Devine, C.K., Steward, S.M., Hojo, D., Na, J.-S., Jur. J.S. \& Parsons, G.N., 2010, Atomic layer deposition and abrupt wetting transitions on nonwoven polypropylene and woven cotton fabrics, Langmuir, Vol. 26: 25502558.

Hu, Z. \& Turner, C.H., 2006, Initial surface reactions of $\mathrm{TiO}_{2}$ atomic layer deposition onto $\mathrm{SiO}_{2}$ surfaces: Density functional theory calculations, Journal of Physics and Chemistry B, Vol. 110: 8337-8347.

Jiang, X., Huang, H., Prinz, F. \& Bent, S.F., 2008, Application of atomic layer deposition of platinum to solid oxide fuel cells, Chemistry of Materials, Vol. 20: 3897-3905.

Johnson, R.W., Hultqvist, A. \& Bent, S.F., 2014, A brief review of atomic layer deposition: from fundamental to applications, Materials Today, Vol. 17: 236-246.

Jur, J.S. \& Parsons, G.N., 2011, Atomic layer deposition of $\mathrm{Al}_{2} \mathrm{O}_{3}$ and $\mathrm{ZnO}$ at atmospheric pressure in a flow tube reactor, ACS Applied Materials \& Interfaces, Vol. 3: 299-308.

Kaipio, M., Blanquart, T., Tomczak, Y., Niinistö, J., Gavagnin, M., Longo, V., Wanzenböck, H.D., Pallem, V.R., Dussarrat, C., Puukilainen, E., Ritala, M. \& Leskelä, M., 2014, Atomic layer deposition, characterization, and growth mechanistic studies of $\mathrm{TiO}_{2}$ thin films, Langmuir, Vol. 30: 7295-7404.

Kim, S., Lee, S., Ham, S.Y., Ko, D.H., Shin, S. \& Jin, Z., 2019, A kinetic study of $\mathrm{ZnO}$ atomic layer deposition: Effects of surface hydroxyl concentration and steric hindrance, Applied Surface Science, Vol. 469: 804-810.

Knez, M., 2012, Diffusion phenomena in atomic layer deposition, Semiconductor Science and Technology, Vol. 27: 074001-074008.

Meng, X., Yang, X.Q. \& Sun, X., 2012, Emerging applications of atomic layer deposition for lithium-ion battery studies, Advanced Materials, Vol. 24: 3589-3615.

Meng, X., Wang, X., Geng, D., Ozgit-Akgun, C., Schneider, N. \& Elam, J.W., 2017, Atomic layer deposition for nanomaterial synthesis and functionalization in energy technology, Materials Horizons, Vol. 4:133-154.

Mukhopadhyay, A.B. \& Musgrave, C.B., 2006, Non-growth ligand exchange reactions in atomic layer deposition of $\mathrm{HfO}_{2}$, Chemical Physics Letters, Vol. 421: 215-220.

Mukhopadhyay, A.B., Musgrave, C.B. \& Sanz, J.F., 2008, Atomic layer deposition of Hafnium oxide from Hafnium chloride and water, Journal of American Chemical Society, Vol. 130: 11996-12006.

Ponraj, J.S., Attolini, G. \& Bosi, M., 2013, Review on atomic layer deposition and applications of oxide thin films, Critical Reviews in Solid State and Materials Sciences, Vol. 38: 203-233.

Pore, V., Hatanpää, T., Ritala, M. \& Leskelä, M., 2009, Atomic layer deposition of metal tellurides and selenides using alkylsilyl compounds of tellurium and selenium, Journal of the American Ceramic Society, Vol. 131: 3478-3480.

Puurunen, R.L., Vandervorst, W., Besling, W.F.A., Richard, O., Bender, H., Conard, T., Zhao, C., Delabie, A., Caymax, M., Gendt, S.D., Heyns, M., Viitanen, M.M.,
Ridder, M., Brongersma, H.H., Tamminga, Y., Dao, T., Win, T., Verheijen, M., Kaiser, M. \& Tuominen, M., 2004, Island growth in the atomic layer deposition of zirconium oxide and aluminum oxide on hydrogenterminated silicon: Growth mode modeling and transmission electron microscopy, Journal of Applied Physics, Vol. 96: 4878-4889.

Puurunen, R.L., 2003, Growth per cycle in atomic layer deposition: Real application examples of a theoretical model, Chemical Vapor Deposition, Vol. 9: 327-332.

Puurunen, R.L., 2004, Analysis of hydroxyl group controlled atomic layer deposition of hafnium dioxide from hafnium tetrachloride and water, Journal of Applied Physics, Vol. 95: 4777-4786.

Spagnola, J.C., Gong, B., Arvidson, S.A., Khan, S.A. \& Parsons, G.N., 2010, Surface and sub-surface reactions during low temperature aluminum oxide atomic layer deposition on fiber-forming polymers, Journal of Material Chemistry, Vol. 20: 4213-4222.

Suntola, T. \& Hyvarinen, J., 1985, Atomic layer epitaxy, Annual Review of Materials Science, Vol. 15: 177-195.

Wilson, C.A., Grubbs, R.K. \& George, S.M., 2005, Nucleation and growth during $\mathrm{Al}_{2} \mathrm{O}_{3}$ atomic layer deposition on polymers, Chemistry of Materials, Vol. 17: 5625-5634.

$\mathrm{Xu}$, Y. \& Musgrave, C.B., 2004, A DFT study of the $\mathrm{Al}_{2} \mathrm{O}_{3}$ atomic layer deposition on SAMs: Effect of SAM termination, Chemistry of Material, Vol. 16: 646-653. 